\title{
Quality of life at work in a central sterile processing department
}

\author{
Qualidade de vida no trabalho numa central de materiais e esterilização \\ Calidad de vida en el trabajo en una central de materiales y esterilización
}

Gliccia Morguethe Vieira Rego' ORCID:0000-0002-4991-4888

Isaura Letícia Tavares Palmeira Rolim' ORCID: 0000-0002-8453-2543

Aurean D'Eça Júnior' ORCID: 0000-0002-7675-412X

Ana Hélia de Lima Sardinha' ORCID: 0000-0002-8720-6348

Geysa Santos Góis Lopes' ORCID: 0000-0002-6801-1940

Nair Portela Silva Coutinho' ORCID: 0000-0002-2050-026X

'Universidade Federal do Maranhão. São Luís, Maranhão, Brazil.

How to cite this article:

Rego GMV, Rolim ILTP, D'Eça Jr A, Sardinha AHL, Lopes GSG, Coutinho NPS. Quality of life at work in a central sterile processing department. Rev Bras Enferm. 2020;73(2):e20180792. doi: http://dx.doi.org/10.1590/0034-7167-2018-0792

Corresponding Author:

Isaura Letícia Tavares Palmeira Rolim

E-mail: leticiaprolim@yahoo.com.br

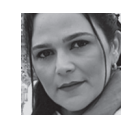

EDITOR IN CHIEF: Antonio José de Almeida Filho ASSOCIATE EDITOR: Hugo Fernandes

Submission: 10-20-2018 Approval: 03-20-2019

\begin{abstract}
Objectives: to evaluate the quality of life of nursing professionals who work in a central sterile processing department. Methods: a descriptive, quantitative, exploratory study, conducted with 82 nursing professionals working in the Central Sterile Processing Department of a University Hospital, from September to November 2017. A semi-structured instrument and the questionnaire "Medical Outcomes Study Short-Form 36" were used. Results: most of the participants were female, married, aged $31-40$ years; $47.6 \%$ with $6-10$ years of profession, and $82.9 \%$ reported working in CSPD for 1-5 years. The most affected quality of life domains were Pain, Vitality, General Health Status and Social Aspects. Conclusions: This study showed a need for rethinking and re-creating the labor dynamics in CSPD to improve the quality of life of these nursing professionals.

Descriptors: Quality of Life; Work; Nursing Team; Sterelization; Occupational Health.
\end{abstract}

\section{RESUMO}

Objetivos: avaliar a qualidade de vida dos profissionais de enfermagem que atuam em uma central de materiais e esterilização (CME). Métodos: estudo exploratório, descritivo, quantitativo, realizado com 82 profissionais da enfermagem que atuavam na central de materiais e esterilização de um hospital universitário, no período de setembro a novembro de 2017. Foi aplicado um instrumento semiestruturado e um questionário, "Medical Outcomes Study Short-Form 36". Resultados: os participantes eram, em maioria, do sexo feminino, casados, na faixa etária de 31-40 anos; 47,6\% tinham de 6-10 anos de profissão e $82,9 \%$ referiram tempo de serviço em CME de 1-5 anos. Os domínios de qualidade de vida mais atingidos foram Dor, Vitalidade, Estado Geral de Saúde e Aspectos Sociais. Conclusões: $O$ estudo mostrou que é preciso repensar e recriar a dinâmica do trabalho em CME na perspectiva de melhorar a qualidade de vida desses profissionais de enfermagem. Descritores: Qualidade de Vida; Trabalho; Equipe de Enfermagem; Esterilização; Saúde do Trabalhador.

\section{RESUMEN}

Objetivos: evaluar la calidad de vida de los profesionales de enfermería que actúan en una central de materiales y esterilización. Métodos: estudio exploratorio, descriptivo, cuantitativo, realizado con 82 profesionales de enfermería que actuaban en una central de materiales y esterilización (CME) de un Hospital Universitario, en el período de septiembre a noviembre de 2017. Se utilizó un instrumento semiestructurado y el cuestionario Medical Outcomes Study Short-Form 36. Resultados: los participantes eran, en su mayoría, del sexo femenino, estaban casados y en el grupo de edad de 31-40 años; El 47,6\% tenía entre 6-10 años de profesión y el 82,9\% mencionó el tiempo de servicio en CME de 1-5 años. Los Dominios de calidad de vida más frecuentes fueron Dolor, Vitalidad, Estado General de Salud y Aspectos Sociales. Conclusiones: El estudio reveló que es necesario repensar y recrear la dinámica del trabajo en CME para que se mejore la calidad de vida de esos profesionales de enfermería. Descriptores: Calidad de Vida; Trabajo; Equipo de Enfermería; Esterilización; Salud del Trabajador. 


\section{INTRODUCTION}

The quality of life at work is complex and involves many aspects, such as: the satisfaction with the work done, the possibility of future in the organization, the recognition of the results achieved, the pay, the benefits, the human relationships on the staff and organization, the psychological and physical work environment, the freedom to act, the responsibility of making decisions, and the possibility of being engaged and participating actively in the organization ${ }^{(1-2)}$.

When discussing the relationship between the individual with his/her work environment, considering that people spend most of their time involved with work, living in institutions with their professional colleagues, is necessary. The hospital environment must be a healthy environment, since the practice of health is characterized by activities that require high interaction between the professionals who form the team. In this case, the relationships and the motivation to perform the activities are essential aspects to pursuit greater efficiency and quality in the care for the patient, which must not be dissociated from the workers' satisfaction with their tasks ${ }^{(3)}$.

Central Sterile Processing Department (CSPD) is the hospital sector of supply of products essential for care. It is subordinate to the nursing service and is considered a technical support unit, which aims to provide health products properly processed, thus providing conditions for direct attention and healthcare for hospitalized individuals ${ }^{(4)}$.

Defined as a functional unit for the processing of health products, the CSPD is a vital and fundamental unit in hospitals, aimed at providing contamination-free materials to be used in a wide range of procedures. Its mission is to establish care and diagnosis services with sterilized health products, ensuring the quantity and quality required for a safe care ${ }^{(5-6)}$.

The nursing staff working at CSPD faces a series of challenges mainly to manage human resources and material to optimize results that meet the demands from various sectors of the institution ${ }^{(7)}$.

In the CSPD, the role of the nurse starts from the planning phase of the unit, being responsible for choosing properly both material and human resources, as well as for the selection and training of staff considering the profile of the sector. In addition, he/she is responsible for coordinating activities, guidance and supervision of all stages of the reprocessing of products and establishment of interfaces with the consumer units ${ }^{(8)}$.

CSPD workers keep an accelerated pace of work, with physical and mental demands, exposed to chemical, physical and biological risks, in addition to working in a physical space that is unfavorable at times. All these factors cause wear, anxiety and fear, affecting not only their health but also the service quality ${ }^{(9)}$.

Given that the worker's quality of life directly influences the quality of the service offered, more and more studies address this topic; however, other studies are required to allow further reflection on this subject in such a critical and closed sector, whose domain is restricted to nursing, which is CSPD.

\section{OBJECTIVES}

To evaluate the quality of life of nursing professionals who work in a Central Sterile Processing Department.

\section{METHODS}

\section{Ethical aspects}

This study was approved by the Research Ethics Committee of the University Hospital of the Federal University of Maranhão, fulfilling the Resolutions 466/12 and 510/16, and the participants learned of the objectives of this study and signed the ICF at the data collection.

\section{Study design, location and period}

A descriptive, quantitative, exploratory study, conducted from September to November 2017, in a central sterile processing department of a university hospital in the Northeastern Brazil. The institution that supported the study is public and reference in the State, it aims to integrate care, teaching, research, and extension in the health field, in addition to comprising the organic structure of the Unified Health System (SUS).

\section{Population, inclusion and exclusion criteria}

The population consisted of 15 nurses and 67 nurse technicians. The professionals who agreed to participate and met the inclusion criteria were included in the study. The criteria adopted were to be a member of the nursing staff and to work at CSPD for at least one year. The losses regarding the population were related to professionals who, during the study, were not performing their activities due to vacation or leave.

\section{Study protocol}

The survey was conducted in two stages: initially, a semi-structured instrument created by the researchers themselves was used for collecting demographic (gender, age, race, marital status, occupation, income) and professional data (occupational category, length of service in CSPD, workload and work shift). Then, to evaluate the quality of life, the questionnaire"Medical Outcomes Study 36-Item Short-Form Study Health Survey (SF-36), a generic measure widely used around the world in various types of population, was used.

The SF-36 is composed of 36 questions, which derive from eight health scales or domains: functional capacity, physical aspects, body ache, general health status, vitality, social aspects, emotional aspects and mental health.

For evaluating the results, after its administration, each question obtains a a score that is subsequently transformed into a scale from zero to 100 , in which zero corresponds to the worst health status and 100 to the best health status, and each domain is analyzed separately. There is no a single value to summarize all the evaluation, resulting in a general health status, better or worse. Thus, an average score is obtained: a higher score indicates better health status or quality of life and lower scores, worse status or impaired quality of life. The calculation of the SF-36 scores result in the so-called Raw Scale, because the final value do not have a unit of measurement ${ }^{(10-11)}$.

\section{Analysis of results and statistics}

The data was tabulated in Microsoft Excel ${ }^{\circledR} 2013$, and the statistical analysis of the results was carried out in the statistical 
program SPSS (Version 22). The data were presented as relative and absolute frequency, mean and standard deviation.

\section{RESULTS}

Eighty-two employees of the nursing staff were interviewed, distributed into nurses and nursing technicians. Table 1 shows the results of the sample identification regarding occupational category, gender, marital status, age, length of service in nursing, length of service in CSPD, time and work shift.

Table 1 shows most of the professionals are nursing technicians $(81.7 \%)$, female (72\%), married (47.6\%), aged between 31 and 40 years $(46.3 \%)$, working from 6 to 10 years in the profession (47.6\%). The length of service in CSPD ranged from 1 year to more than 11 years, and $82.9 \%$ of the professionals worked between 1 and 5 years. Regarding the variable work schedule, $50 \%$ of the professionals work in the day shift (morning or afternoon) and $43.9 \%(n=36)$ work in mixed or alternating shifts, that is, work both in the daytime and night time.

Table 2 shows the list of the scores obtained according to the answer to the SF-36 questionnaire used for assessment of the workers' quality of life in Central Sterile Processing Department.

Table 1 - Demographic and professional characterization of nursing professionals who work in a Central Sterile Processing Department, São Luís, Maranhão, Brazil, 2017

\begin{tabular}{|c|c|c|}
\hline Variables & $\mathbf{n}$ & $\%$ \\
\hline \multicolumn{3}{|l|}{ Occupational category } \\
\hline Nurse & 15 & 18.3 \\
\hline Nursing Technician & 67 & 81.7 \\
\hline \multicolumn{3}{|l|}{ Gender } \\
\hline Female & 59 & 72.0 \\
\hline Male & 23 & 28.0 \\
\hline \multicolumn{3}{|l|}{ Age (years) } \\
\hline from 20 to 30 & 15 & 18.3 \\
\hline from 31 to 40 & 38 & 46.3 \\
\hline from 41 to 50 & 21 & 25.6 \\
\hline from 51 to 60 & 5 & 6.1 \\
\hline Over 60 & 3 & 3.7 \\
\hline \multicolumn{3}{|l|}{ Marital status } \\
\hline Married & 39 & 47.6 \\
\hline Divorced & 4 & 4.9 \\
\hline Single & 37 & 45.1 \\
\hline Widow/Widower & 2 & 2.4 \\
\hline \multicolumn{3}{|l|}{ Years of profession } \\
\hline from 1 to 5 & 14 & 17.1 \\
\hline from 6 to 10 & 39 & 47.6 \\
\hline from 11 to 15 & 14 & 17.1 \\
\hline from 16 to 20 & 11 & 13.4 \\
\hline More than 20 & 4 & 4.9 \\
\hline \multicolumn{3}{|c|}{ Length of service in CSPD (years) } \\
\hline from 1 to 5 & 68 & 82.9 \\
\hline from 6 to 10 & 9 & 11.0 \\
\hline More than 11 & 5 & 6.1 \\
\hline \multicolumn{3}{|l|}{ Work schedule } \\
\hline Daytime & 41 & 50.0 \\
\hline Mixed & 36 & 43.9 \\
\hline Nighttime & 5 & 6.1 \\
\hline Total & 82 & 100.0 \\
\hline
\end{tabular}

In this study, the SF-36 questionnaire was administered once, and Table 2 evidences that all the values obtained in the score of the eight domains assessed reaches the maximum value, which is 100 (the best health status), corresponding to a better assessment of the health status of the population studied. Also, in all the domains, at least one individual shows impaired health, which is justified, in all domains, by the minimum value lower than 50 , reaching a value 0 (the worst health status).

Table 3 shows the percentage of participants present in each domain, with scores lower or higher than 50, highlighting the most affected domains of quality of life. Pain was the most affected domain, followed by vitality and general health status. Emotional aspect was the domain that showed the highest score.

Table 3 - Characterization of the quality of life of nursing professionals who work in a Central Sterile Processing Department through the SF-3, São Luís, Maranhão, Brazil, 2017

\begin{tabular}{lcccc}
\hline & \multicolumn{5}{c}{ Score } \\
Domains & $\mathbf{5 0}$ or more & Lower than $\mathbf{5 0}$ \\
& $\mathbf{n}$ & $\mathbf{\%}$ & $\mathbf{n}$ & $\mathbf{\%}$ \\
\hline \multirow{2}{*}{ Pain } & 54 & 65.9 & 28 & 34.1 \\
Vitality & 61 & 74.4 & 21 & 25.6 \\
General health status & 63 & 76.8 & 19 & 23.2 \\
Social aspects & 67 & 81.7 & 15 & 18.3 \\
Mental health & 68 & 82.9 & 14 & 17.1 \\
Functional capacity & 69 & 84.1 & 67 & 81.7 \\
Limitation due to physical aspects & 76 & 92.7 & 6 & 7.3 \\
Limitation due to emotional aspects & 76 & 92.7 & 6 & 7.3 \\
& & & & \\
\hline
\end{tabular}

\section{DISCUSSION}

For a better contextualization of the results, one highlights that the place chosen for this study (CSPD) is one of the few sectors in a hospital that is exclusive to nursing, a place for the category, assigning the responsibility for the proper functioning of the hospital to the nursing staff.

One found that the female sex was prevalent among the workers surveyed (72\%), a fact already expected, which was ratified in this study, showing nursing is still a profession with female hegemony. This finding corroborates several studies, such as one conducted in Cuiabá, in 2014, and another in 2017 in a hospital in Palmas, TO, Brazil ${ }^{(12-13)}$.

The prevalence of women in nursing is observed not only in Brazil, but also in other countries, as shown in a study conducted in Andalusia, in Spain, in which $66 \%$ of a total of 676 nurses were 
female and in another one carried out in Arequipa, Peru, in which $96.3 \%$ of a total of 81 nurses were female ${ }^{(14-15)}$.

Studies report that the predominance of women in nursing is explained by its paradigm, created in a distant time, in the period before Christ, in which the act of caring for other people and sick has always been culturally more related to woman than to man ${ }^{(16)}$.

Special attention must be given to the high number of female professionals in a sector such as a center of materials, since it involves activities of great physical effort such as assembling and carrying heavy surgical boxes and handling with autoclaves. Overuse of muscle strength and overspending of physical strength has caused postural problems and general fatigue in workers, becoming more serious with the predominance of women in the work force of a hospital ${ }^{(17)}$.

The average age found in this study was similar to that from a study carried out in 2016, in the municipality of Rio de Janeiro, and are also close to the data made available by the Brazilian Institute of Geography and Statistics (IBGE), since most people of the workingage in all regions of Brazil is aged between 25 and 49 years ${ }^{(18-19)}$.

This study points to the predominance of average age of young adults (64.6\%). However, the presence of people over 50 years old (9.8\%) engaged in this type of activity, which is a worrying aspect, should be emphasized. In practice, one observes that these workers are assigned to do activities that require less physical effort, but we must remember that virtually all activities of a central sterile processing department, in addition to requiring physical strength, are repetitive and/or monotonous chores that complete a set of processing and control necessary for productivity. In addition, these activities require the employee to be in uncomfortable positions for several hours for doing his/her work. Also, with the relocation of these workers for "lighter" services, younger employees are overloaded and can get sick even earlier than expected. The employees point the physical workloads as a great difficulty in carrying out their work, affecting their quality of life ${ }^{(20)}$.

Regarding marital status, the results show most of the workers were married (47.6\%), corroborating a study with 393 nursing professionals of three hospitals in the municipality of Alfenas, MG, Brazil, where most of them are married or live with partners, corresponding to $54.7 \%$ (215) of the participants ${ }^{(21)}$. Maintaining affective bonds with others, building family (to marry and have and raise children), as well as sharing activities, interests and opinions with loved ones are factors that influence positively the quality of life of any human being, once man is, by his very nature, a social being ${ }^{(22)}$.

Regarding the years of profession and length of service in CSPD, in this study (4.9\%) professionals who work for more than 20 years in the profession of nursing, and $6.1 \%$ exercise activities for over 11 years in CME. In a study carried out in the countryside of Paraná, this value was much higher, because $25 \%$ of respondents worked for more than 10 years in CSPD $^{(23)}$.

Special attention must be given to length of service in CSPD, since the longer the time providing this service, the greater the chances of developing injuries and illnesses, because, as mentioned above, the activities developed in CSPD are repetitive and/or tedious, requiring extensive physical effort.

In a study conducted in the Distrito Federal, which assessed the prevalence of musculoskeletal injuries in workers of the central sterile processing department, $61.3 \%$ of respondents had any type of musculoskeletal injury, which is worsened over the years when carrying out the same activities. In this study, the occurrence of musculoskeletal injuries was not investigated; however, it would be interesting to consider this investigation, associating the occurrence of injury with the length of service in nursing and in CSPD $^{(24)}$.

Regarding the work shift, $50 \%$ of the participants of this study worked in the daytime shift, $43.9 \%$ in the mixed shift (day and night) and $6.1 \%$ in the night shift, that is, the proportion of workers who do their activities in the daytime or nighttime is somewhat equivalent, not corroborating studies in which $70.59 \%$ worked in the daytime shift ${ }^{(25)}$.

The night work changes ones' life, since changing the sleepwake cycle leads to negative consequences both in the biological aspect, such as the emergence of obesity, ulcers, irritability and tiredness, and in the psychological aspect ${ }^{(26)}$.

Sleep deprivation is becoming more usual today, and people reduce the amount of hours spent sleeping to perform other tasks. The neurobiological processes that occur during the sleeping period are essential for the maintenance of cognitive and physical health, as individuals with sleep disorders suffer impacts on quality of life without being working and during the work period ${ }^{(27)}$.

In a study conducted with 21 nurses in New York, United States, on the impact of night work on social and family life showed most of them needs to make efforts to start and keep sleeping after work. Most of them planned a routine for fulfilling daily responsibilities in which rest takes a back seat. Other nurses preferred to sleep shortly after finishing their working period and then to meet their family obligations. All participants, without exception, reported that the nighttime sleep was the most restorer ${ }^{(28)}$.

In Table 3, when analyzing the study data, in all the domains of the SF-36 at least a worker shows health injury, evidenced by the minimum value lower than 50. Pain was the most affected domain, followed by vitality and general health status.

For pain, $34.1 \%$ of participants showed scores lower than 50 , which can be related to physical wear to which these workers are subjected in the workplace. A study carried out in 2017, with 135 employees of the nursing staff, evidenced that the nonspecific low back pain is one of the most common occupational health problems and that workers who spend more time in standing position allege back pain more often than those who spend more time in sitting position ${ }^{(29)}$.

In another study, $42 \%$ of the participants had sick leave, having the musculoskeletal injury as a reason. Pain is the main responsible for lack of work, sick leaves, retirements because of illnesses, workers' compensation and low labor productivity ${ }^{(24,30)}$.

Vitality was the second most affected domain: $25.6 \%$ showed scores lower than 50. Vitality considers the level of energy of each individual (full of physical vigor, a lot of energy), as well as of fatigue (worn out, tired). A study carried out in São Paulo, SP, Brazil, showed how notifications of musculoskeletal system diseases are frequent and pointed that the exposure to physiological loads is caused by the use of body as work instrument, and in this exposure several wear processes, such as musculoskeletal disorders, fatigue, pain in general and changes in the circadian rhythm due to night work, may occur ${ }^{(30)}$.

The third domain affected was the general health status, which includes questions related to the viewpoint of the worker about his/her own health: $23.2 \%$ of participants showed scores lower 
than 50. The general health status is more than the situation of physical health itself, it goes beyond the absence of disease and relates to a subjective perception of the individual. In this domain, when the individual reflects on his/her health, he/she makes a retrospective and comprehensive analysis.

\section{Study limitations}

Even though the SF-36 questionnaire is an instrument widely used in national and international studies, it results in a general health status, better or worse. Thus, the general health status, the impact of this study and its direct impacts on the professionals' quality of life cannot be predicted with more rigor and depth. The questionnaire SF-36 has a fundamental importance in pointing the workers' health status; however, the influences of the workplace relationships on the professionals' health require qualitative studies.

\section{Contributions to the fields of nursing, health or public policy}

Therefore, one can say that pain and vitality, which were the most affected domains, can alert to the need for identifying inappropriate aspects in the workplace.
The estimation is that the findings of this study can contribute to reflection on the quality of life of these professionals on the part of the nursing staff, the academic community and the users of health services. One understands that the findings of this investigation are extremely important, once it reveals points that can be improved through the management of nursing services.

\section{CONCLUSIONS}

The most affected domains of quality of life were Pain, Vitality, General Health Status and Social Aspects.

The results of this study broadened the understanding of the problems affecting the quality of life of the nursing staff of a Central Sterile Processing Department. Currently, much is said about quality of life and quality of life at work, but these aspects depend on the context that involves each person's individuality and on each person's perception of the topic. The presence of pain, impairment of vitality, as well as of the general health status and social aspects affected will interfere greatly with the CSPD worker's quality of life.

Thus, rethinking the ways of work and of interaction between people, using technologies for the nursing professional's health, is necessary, especially in sectors such as CSPD, a specific sector in which there is a huge physical and emotional wear.

\section{REFERENCES}

1. Chiavenato I. Gestão de pessoas: o novo papel dos recursos humanos nas organizações. 3a ed. Rio de Janeiro: Elsevier; 2010.

2. Ramos EL, Souza NVDO, Gonçalves FGA, Pires AS, Santos DM. Quality of work life: repercussions for the health of nursing worker in intensive care. J Res Fundam Care Online. 2014;6(2):571-83. doi: 10.9789/2175-5361.2014v6n2p571

3. Renner JS, Taschetto DVR, Baptista GL, Basso CR. Quality of life and work satisfaction: the perception of nursing technicians who work in the hospital environment. REME - Rev Min Enferm. 2014;18(2):447-53. doi: 10.5935/1415-2762.20140033

4. Vasconcelos GA, Costa MR, Campelo DCCA. Conhecimento da equipe de enfermagem de uma central de material sobre reprocessamento de artigos de uso único. Rev Pesq Saúde [Internet]. 2014 [cited 2019 Feb 04];15(2):267-71. Available from: http://www.periodicoseletronicos. ufma.br/index.php/revistahuufma/article/view/3262/1304

5. Ministério da Saúde (BR). Agência Nacional de Vigilância Sanitária (ANVISA). Resolução - RDC n 15, de 15 de março de 2012. Dispõe sobre requisitos de boas práticas para o processamento de produtos para saúde e dá outras providências [Internet]. Brasília: Ministério da Saúde; 2012 [cited 2018 Mar 5]. Available from: http://bvsms.saude.gov.br/bvs/saudelegis/anvisa/2012/rdc0015_15_03_2012.html.

6. Associação Brasileira de Enfermeiros de Centro Cirúrgico, Recuperação Anestésica e Centro de Material e Esterelização (SOBECC). Diretrizes de práticas em enfermagem cirúrgica e processamento de produtos para a saúde. 7a ed. Barueri: Manole; 2017.

7. Neis MB, Gelbcke FL. Carga de trabalho em centro de material e esterilização: subsídios para dimensionar pessoal de enfermagem. Rev Eletr Enf. 2013;15(1):15-24. doi: 10.5216/ree.v15i1.17314

8. Carvalho EL, Silva MRB, Campelo SMA, Alencar DC, Moreira WC. Qualidade de vida dos trabalhadores de Enfermagem de um centro de material e esterilização. R Interd [Internet]. 2016 [cited 2019 Feb 4];9(3):67-73. Available from: https://revistainterdisciplinar.uninovafapi.edu. br/index.php/revinter/article/view/1011/pdf_341

9. Ouriques CM, Machado ME. Nursing in the process of sterilization of materials. Texto Contexto Enferm. 2013;22(3):695-703. doi: 10.1590/ S0104-07072013000300016

10. Ware JE. SF-36 health survey: manual and interpretation guide. Boston: New England Medical Center; 1993.

11. Ware JE Jr, Kosinski M, Bayliss MS, McHorney CA, Rogers WH, Raczek A. Comparison of methods for the scoring and statistical analysis of SF36 health profile and summary measures: summary of results from the medical outcomes study. Med Care. 1995;33(4 Suppl):AS264-79.

12. Borges T, Bianchini MA. Qualidade de vida dos profissionais de enfermagem de um hospital universitário do interior de São Paulo. Arq Ciênc Saúde. 2015;22(1):53-8. doi: 10.17696/2318-3691.22.1.2015.29

13. Soares JP, Barbosa TC, Silva BKR, Zica MM, Maciel ES, Batello GVVAT, et al. Qualidade de vida, estresse, nível de atividade física e cronotipo dos auxiliares/técnicos de enfermagem em unidades de pronto atendimento em Palmas/TO. Rev CPAQV [Internet]. 2017 [cited 2019 Feb 04];9(1):19. Available from: http://www.cpaqv.org/revista/CPAQV/ojs-2.3.7/index.php?journal=CPAQV\&page=article\&op=view\&path\%5B $\% 5 \mathrm{D}=180$ 
14. Cañadas-De La Fuente GA, Vargas C, San Luis C, García I, Cañadas GR, De La Fuente El. Risk factors and prevalence of burnout syndrome in the nursing profession. Int J Nurs Stud. 2015;52(1):240-9. doi: 10.1016/j.ijnurstu.2014.07.001

15. Condori A, Gonzales YMA, Verónica J. Calidad de vida laboral y desempeño del profesional de enfermería [monografia] [Internet]. Arequipa: Universidad Nacional de San Agustín; 2017 [cited 2019 Feb 04]. Available from: http://repositorio.ucv.edu.pe/handle/UCV/16873

16. Almeida DB, Queirós PJP, Silva GTR, Laitano ADC, Almeida SS. Sexist stereotypes in portuguese nursing: a historical study in the period 1935 to 1974. Esc Anna Nery. 2016;20(2):228-35. doi: 10.5935/1414-8145.20160030

17. Shoji S, Souza NVDO, Farias SNP, Vieira MLC, Progianti JM. Proposta de melhoria das condições de trabalho em uma unidade ambulatorial: perspectiva da enfermagem. Esc Anna Nery. 2016;20(2):303-9. doi: 10.5935/1414-8145.20160041

18. Costa CCP, Souza NVDO, Pires AS. Profile of workers of a material and sterilization: an analysis of social and professional characteristics. J Res Fundam Care Online. 2016;8(1):3633-45. doi: 10.9789/2175-5361.2016.v8i1.3633-3645

19. Instituto Brasileiro de Geografia e Estatística (IBGE). Indicadores IBGE: pesquisa mensal de emprego - dezembro de 2013 [Internet]. Rio de Janeiro: IBGE; 2014 [cited 2019 Feb 04]. Available from: https://www.ibge.gov.br/estatisticas/sociais/trabalho/9180-pesquisa-mensal-deemprego.html

20. Vargas E, Azambuja EP, Kerber NPC, Santos CP, Strefling IS, Silva IR. Qualidade de vida no trabalho da enfermagem: influência de cargas físicas no trabalho em centro cirúrgico. Congrega URCAMP [Internet]. 2017 [cited 2019 Feb 04]:236-49. Available from: http://trabalhos. congrega.urcamp.edu.br/index.php/14jpgp/article/view/2658

21. Nascimento MGG, Nadaleti NP, Vilela SC, Terra FS, Silva SA, Resck ZMR. Nursing work process in the promotion of mental health: reflective analysis. Rev Enferm Cent-Oeste Min. 2017;7:e1391. doi: 10.19175/recom.v7i0.2097

22. Goldani AM. Famílias e gêneros: uma proposta para avaliar (des)igualdades. In.: Anais do XII Encontro Nacional de Estudos Populacionais; 2000 Oct 23-27 [Internet]. São Paulo: Associação Brasileira de Estudos Populacionais (ABEP); 2016 [cited 2019 Feb 04]. Available from: http:// www.abep.org.br/publicacoes/index.php/anais/article/view/982

23. Bugs TV, Rigo DFH, Bohrer CD, Borges F, Marques LGS, Vasconcelos RO, et al. Profile of the nursing staff and perceptions of the work performed in a materials center. Rev Min Enferm. 2017;21:e996. doi: 10.5935/1415-2762.20170006

24. Costa CRS, Almeida FCS, Trevisan J. Prevalência das lesões osteomusculares nos servidores da central de material e esterilização de um hospital público do Distrito Federal. In: Anais do Simpósio ICESP; 2016 Oct. 6-7 [Internet]. Brasília: Faculdade Promove; 2016 [cited 2019 Feb 04]. Available from: http://nippromove.hospedagemdesites.ws/anais_simposio/arquivos_up/documentos/artigos/0c201ab57292f0e74fde2 c0da7ea8815.pdf

25. Silva AA, Rotenberg L, Fischer FM. Nursing work hours: individual needs versus working conditions. Rev Saúde Pública. 2011;45(6):1-9. doi: $10.1590 /$ S0034-89102011000600014

26. Ravagnani JS, Crivelaro PMS. Qualidade de sono e percepção da qualidade de vida dos profissionais de enfermagem de uma Unidade de Terapia Intensiva [monografia] [Internet]. Lins: Centro Universitário Católico Salesiano Auxílium; 2010 [cited 2019 Feb 04]. Available from: http://www.unisalesiano.edu.br/biblioteca/monografias/51939.pdf

27. Vitale SA, Varrone-Ganesh J, Vu M. Nurses working the night shift: impact on home, family and social life. J Nurs Educ Pract. 2015;5(10):70-8. doi: 10.5430/jnep.v5n10p70

28. Teixeira MS, Horn TL, Macedo DS, Santos AC. Relação entre dor lombar inespecífica e capacidade funcional de trabalhadores do serviço de enfermagem de um hospital universitário. Clin Biomed Res [Internet]. 2017 [cited 2019 Feb 05];37(Supl):125. Available from: https://www. hcpa.edu.br/downloads/pesquisa/RevistaCientifica/2017/anais_semana_cient_hcpa_2017.pdf

29. Almeida DR, Lima GS. Conhecendo os principais sintomas da doença osteomuscular (LER-DORT) que acometem profissionais de enfermagem de uma clínica do Hospital Regional de Cáceres Doutor Antônio Fontes, Mato Grosso, Brasil. Rev Gestão Saúde [Internet]. 2014 [cited 2019 Feb 5];5(4):2607-31. Available from: http://periodicos.unb.br/index.php/rgs/article/view/1121/973

30. Felli VEA, Costa TF, Baptista PCP, Guimarães ALO, Anginoni BM. Exposure of nursing workers to workloads and their consequences. Rev Esc Enferm USP. 2015;49(esp 2):96-103. doi: 10.1590/S0080-623420150000800014 